ASE-14-0043 REVISED

Descriptive article

\title{
Implementation of an Education-Focused PhD \\ Program in Anatomy and Cell Biology at Indiana University: \\ Lessons Learned and Future Challenges
}

\author{
James J. Brokaw', Valerie D. O’Loughlin² \\ ${ }^{1}$ Department of Anatomy and Cell Biology, Indiana University School of Medicine, Indianapolis, \\ Indiana \\ ${ }^{2}$ Medical Sciences Program, Indiana University School of Medicine, Bloomington, Indiana
}

Running title: Education Track in Anatomy PhD at IUSM

Correspondence to: Dr. James J. Brokaw, Department of Anatomy and Cell Biology

Indiana University School of Medicine, 635 Barnhill Drive, MS-5035, Indianapolis, IN 46202.

USA. E-mail: jbrokaw@iupui.edu

This is the author's manuscript of the article published in its final form as:

Brokaw, J. J., \& O’Loughlin, V. D. (2015). Implementation of an education-focused PhD program in anatomy and cell biology at Indiana University: Lessons learned and future challenges. Anatomical Sciences Education, 8(3), 258-265. http://doi.org/10.1002/ase.1482 


\section{ABSTRACT}

In 2008, the Indiana University School of Medicine, in collaboration with the School of Education, admitted its first student to a newly approved PhD program in Anatomy and Cell Biology focusing on educational research rather than biomedical research. The goal of the program is twofold: (1) to provide students with extensive training in all of the anatomical disciplines coupled with sufficient teaching experience to assume major educational responsibilities upon graduation and (2) to train students to conduct rigorous medical education research and other scholarly work necessary for promotion and tenure. The 90 credit hour curriculum consists of biomedical courses taught within the School of Medicine and education courses taught within the School of Education, including courses in health sciences pedagogy, curriculum development, learning theory, quantitative and qualitative research methods, statistics, and electives. To date, 16 students have entered the program, 7 have passed their qualifying examinations, and 5 have earned their PhDs. Four students have received national recognition for their educational research and 4 graduates have obtained faculty appointments. Going forward, we must adapt the program's biomedical course requirements to incorporate the new integrated curriculum of the medical school, and we must secure additional funding to support more students. Overcoming these challenges will enable us to continue producing a small but stable supply of doctoral-level anatomy educators for a growing academic market.

Key Words: Educational Research, Anatomy Education, Graduate Education, Scholarship of Teaching and Learning 


\section{INTRODUCTION}

The last several decades have witnessed fundamental changes in the way graduate students are trained in anatomy departments. In many cases, former discipline-specific anatomy departments have been reorganized into interdisciplinary programs to better-compete for federal research grants, some even removing ‘anatomy’ from their names altogether (McCuskey et al., 2005; Hildebrandt, 2010). No longer are graduate students routinely required to learn and teach the traditional anatomical disciplines of gross anatomy, neuroanatomy, histology, and embryology to earn their PhDs (McCuskey et al., 2005; Rizzolo and Drake, 2008). These time-consuming educational experiences are simply not deemed relevant to the future funding prospects of biomedical scientists. For example, the biomedical research PhD track in Anatomy and Cell Biology at the Indiana University School of Medicine (2014a) does not require its students to take a gross anatomy course; rather, students are trained primarily in cellular and molecular biology. Likewise, at Virginia Commonwealth University (2014), the Anatomy and Neurobiology $\mathrm{PhD}$ requires coursework in molecular biology and neuroscience, but no required coursework in gross anatomy or histology. Thus, acquiring an expert knowledge of anatomy, especially gross anatomy, is no longer a universal expectation for earning the $\mathrm{PhD}$.

As classically trained anatomists retire and leave the workforce, they are not being replaced by newly minted PhDs with the requisite training and career focus needed to maintain the anatomy teaching mission (McCuskey et al., 2005; Rizzolo and Drake, 2008). This state of affairs has prompted concerns of an impending shortage of qualified anatomy educators in the nation's medical schools and other health professions institutions (McCuskey et al., 2005; Hedger, 2009). Although the problem is most acute for gross anatomy, similar concerns apply to the other anatomical disciplines (Drake et al., 2009). Who will teach these subjects in the future? 
One approach is to hire teaching staff from the ranks of biological anthropologists, physical therapists, foreign-trained MDs, and others who are knowledgeable about anatomy (McCuskey et al., 2005; O’Loughlin, 2005). Some individuals with PhDs or EdDs in science education also have been hired to fill the gap. Unfortunately, many science education programs are general and may not delve into the anatomy knowledge base as extensively as an anatomy-specific program, leaving graduates with potential deficits in their anatomy knowledge. Another approach is to recruit and train young biomedical scientists to teach anatomy as an adjunct to their research careers. Examples of this approach include the Scientist-Educator Program at Vanderbilt University (Bader et al., 2010) and the Anatomy Training Program co-sponsored by the American Association of Anatomists and the Anatomical Society of Great Britain and Ireland (Fraher and Evans, 2009).

In addition, there are several masters-level graduate programs that have been developed to train instructors of cadaveric gross anatomy. Examples of these programs include those at Western University in Ontario (2014), Tulane University School of Medicine (2014), and Creighton University School of Medicine (2014). (A more complete list of graduate programs may be found on the American Association of Anatomists website [2014].) These Masters programs are noteworthy, but most 4-year and professional schools require their faculty to hold a $\mathrm{PhD}$, so these students may have to undergo additional education should they wish to pursue faculty positions.

There have been a few doctoral-level graduate programs with an emphasis on anatomy education. The University of Utah developed an anatomy educator PhD program (Albertine, 2008), but it currently is being redesigned and has not accepted new students. For many years, Purdue University (2014) offered a PhD degree in Basic Medical Sciences with the option to 
study anatomy pedagogy, but this option is no longer available to students. The University of Nebraska (2014) and Louisiana State University (2014) both offer PhD programs that provide students with extensive anatomy teaching experience as an adjunct to their laboratory-based dissertation research. In 2013, the University of Mississippi (2014) began offering a PhD degree in Clinical Anatomy, in which students are trained to become master anatomy educators and pursue dissertation projects related to anatomy pedagogy or clinical anatomy. According to the information posted on the school's website, this program requires numerous anatomy courses, but it appears not to offer a structured core curriculum of education coursework, so the student may not become well versed in educational research and the scholarship of teaching and learning (SOTL) (Boyer, 1990; Glassick et al., 1997). Also, Western University in Ontario (2014) has reportedly implemented an education-focused PhD program in Clinical Anatomy, though no details were available on the school's website at the time of this writing. These few examples are not intended as a complete listing of all $\mathrm{PhD}$ programs, past and present, with an emphasis on anatomy education. Nevertheless, we believe it is fair to say that such programs are relatively rare.

The hiring strategies and training programs discussed above will not fully satisfy the need for qualified anatomy educators, nor will they produce enough faculty members who are uniquely prepared to advance the scholarship of anatomical education. An alternative approach is to create a new kind of doctoral-level anatomy educator—someone who is specifically trained to teach anatomy as well as conduct rigorous educational research, and whose career advancement derives from the same. In recent years, university science departments have begun to recognize the value of faculty members from traditional scientific disciplines who are formally schooled in educational theory and practice (Bush et al., 2008). These science professors can play a vital role 
not only in the dissemination of discipline-specific knowledge to students, but also in the development and evaluation of new educational interventions and curricula. Medical schools have likewise come to appreciate social science $\mathrm{PhDs}$ who are well versed in educational research methodology, because of the valuable guidance they can offer to the institutional teaching mission (Albert et al., 2007). Unfortunately, there are few avenues for the dual training of biomedical graduate students - the future faculty members of universities and professional schools - in both discipline-specific knowledge and the intricacies of educational research.

In 2008, the Department of Anatomy and Cell Biology of the Indiana University School of Medicine was granted approval to offer a special Education Track in Anatomy PhD Program for individuals seeking careers in anatomical teaching and medical education research, rather than laboratory-based research. In an era of curricular reform, there is a growing need for medical programs to be rigorously assessed for evidence of educational effectiveness (Carney et al., 2004; Bunniss and Kelly, 2010). Few basic science faculty members are qualified to conduct the necessary research, and the Education Track in Anatomy PhD Program is unique in that it prepares students to be qualified medical education researchers, as well as anatomy educators. Ours is not the first anatomy PhD program to accept educational research for the doctoral dissertation, but to the best of our knowledge, ours is the only extant program with a structured core curriculum of education coursework and a sole focus on medical education research. This program exemplifies a highly successful collaboration between the Indiana University School of Medicine and the Indiana University School of Education.

The purpose of this paper is to describe the key features of the Education Track in Anatomy PhD Program, to comment on the lessons we learned during its implementation, and discuss our future challenges. 


\section{THE PROGRAM}

The goal of the Education Track in Anatomy PhD Program is to produce a cadre of doctorallevel anatomy educators who are capable of teaching all of the anatomical disciplines to undergraduate, graduate, and professional students, and who are capable of producing the highquality educational research and other scholarly work necessary for promotion and tenure.

\section{The Curriculum}

Designed as a five-year program, the 90 credit hour curriculum (credit hours are semester-based) consists of biomedical courses taught within the School of Medicine and education courses (doctoral minor) taught within the School of Education, including courses in health sciences pedagogy, curriculum development, learning theory, quantitative and qualitative research methods, statistics, and electives (Table 1). In addition to didactic classes, the Education Track students are required to participate in Journal Club, a monthly seminar series, and supervised teaching and research experiences, all of which are specific to the Education Track in Anatomy $\mathrm{PhD}$ Program and involve PhD faculty from both the School of Medicine and the School of Education.

\section{The Students}

To date, the program has received applications from 75 individuals (an average of about 11 per year), of which 42 (56\%) were female and 33 (44\%) were male. Of these 75 applicants, 11 women and 5 men were accepted into the program from diverse academic backgrounds (Table 2). Most had a master's degree in a relevant discipline and all had prior teaching experience. Accepted students are assigned to either the main medical campus at Indiana University-Purdue 
University Indianapolis (IUPUI) or the Medical Sciences Program located on the campus of Indiana University Bloomington (IUB), which is one of 8 regional campuses comprising IU's distributed system of medical education. The curriculum is essentially the same at both sites and is taught by onsite faculty members in the Schools of Medicine and Education. There are currently 10 students in the program, 5 at each site. Students are supported by teaching stipends provided by the Department of Anatomy and Cell Biology at IUPUI and by the Medical Sciences Program at IUB. The program is capped at 10 students largely due to financial constraints and the availability of suitable research mentors.

\section{Teaching Experience}

In keeping with the program's goal, the Education Track students are provided with ample opportunities to hone their skills in anatomical teaching. In fact, to receive financial support, the students are required to teach every semester they are in the program, including their first and final years. The teaching assignments are made in accordance with each student's progress in the curriculum and prior teaching experience. Students must teach all of the anatomy courses in the medical curriculum (gross anatomy, neuroscience, and histology) at least once during their tenure, for which they are formally evaluated and graded. Other teaching assignments include large undergraduate anatomy courses for pre-professional students, undergraduate embryology courses, anatomy courses for masters-level graduate students, and anatomy courses for physician assistant, physical therapy and osteopathic students, as well as one-on-one tutoring sessions for struggling students. Some of these courses were already 'on the books', while other courses were created and taught by the graduate students themselves. The Education Track students are expected not only to teach in the laboratory, but also to provide classroom lectures and 
participate in small-group teaching activities like problem-based learning (PBL) and team-based learning (TBL). While most teaching opportunities are face-to-face, some courses have a hybrid/blended-learning component of online instruction that the graduate student teachers also experience. The graduate students are encouraged to teach in as many varied settings and courses as possible, and the faculty makes teaching assignments with this goal in mind. Faculty mentors help the students prepare for their teaching roles and offer them feedback about their performance afterwards. Moreover, the students in the classroom formally evaluate the graduate students' teaching.

The development of Education Track students into anatomy teaching scholars is assessed in a variety of ways. Firstly, students take a required health sciences pedagogy course, whereby they compose a statement of teaching philosophy and develop a teaching portfolio (Griffith et al., 2013). The students participate in regularly scheduled educational research seminars and journal clubs, where educational research is discussed as well as teaching challenges and rewards. In addition, graduate student teaching is evaluated not only by the students in the course, but also by the faculty involved in teaching the course. Finally, the students are required to enroll in an anatomy teaching practicum for each semester that they help teach medical students in gross anatomy, histology, and neuroanatomy. This teaching practicum requires students to give formal classroom lectures, hold lecture and laboratory review sessions, conduct laboratory demonstrations, and lead small-group activities such as TBL sessions. Either the course director or another faculty member versed in pedagogy formally evaluates the quality of the teaching and provides formative feedback to the student. At the end of the practicum, students complete a reflective essay about their specific teaching experiences, to be submitted into the teaching portfolio. 


\section{$\underline{\text { Research Experience }}$}

Although demonstrated excellence in anatomical teaching is required of all students in the program, the act of teaching, in of itself, does not constitute scholarship. The $\mathrm{PhD}$ is first and foremost a research degree for which original scholarship is required. What makes the Education Track in Anatomy PhD Program truly unique compared to other biomedical PhD programs is the nature of the research component. Instead of bench research, the Education Track students are trained to conduct rigorous medical education research, culminating in a doctoral dissertation that meets the academic standards of Indiana University. This approach is congruent with the opinions of many anatomy educators who believe that pedagogy and educational research should be emphasized in anatomy training programs (Albertine, 2008; Rizzolo and Drake, 2008; Fraher and Evans, 2009). As mentioned previously, to the best of our knowledge, ours is the only PhD program in anatomy with a sole focus on medical education research.

Medical education research has many of the same features as biomedical research — the major conceptual difference being the outcome of interest (Riehl, 2006). Whereas biomedical research attempts to elucidate the underlying mechanism of some measurable biologic event, medical education research seeks to understand the causal relationships between certain educational variables and measurable learning outcomes. Like biomedical research, medical education research is informed by the relevant literature, draws upon the best practices and methodology in the field, is peer-reviewed, and is made public. Medical education research uses quantitative methods familiar to the biomedical sciences (Carney et al., 2004; Boet et al., 2012), as well as qualitative methods drawn from the traditions of the social sciences (Curry et al, 2009; Bunniss and Kelly, 2010; Boet et al., 2012). The particular methods used are matched to the kinds of research questions for which they are most appropriate (Schifferdecker and Reed, 2009). For 
example, some medical education research is not driven by hypotheses, per se, but by a series of research questions derived from real world setting, which are best answered with techniques and assumptions different from those engendered by the biomedical model of research. Surveys, focus groups, or observations of participant behavior may yield the most useful information, depending on the particular research question (Merriam, 1992; Merriam and Simpson, 2000; Bernard, 2006; Kennedy and Lingard, 2006).

By the end of their first year in the program, the Education Track students are prepared to engage in educational research projects under the direction of experienced educational researchers in the medical school or other academic units where such research is being conducted. Depending on their backgrounds and interests, some students may complete up to 3 semester-long research "rotations" with different educational researchers in the Schools of Medicine, Education, Nursing, or Science to learn new techniques and explore potential opportunities for dissertation projects. From these early research experiences, the students eventually develop their own project ideas and identify suitable mentors with whom to work. Students may pursue a dissertation project about any aspect of medical education, not necessarily anatomy education.

\section{The Dissertation Proposal and the Qualifying Examination}

The focus of the qualifying examination is on the student's dissertation research proposal and his/her ability to independently conduct high-quality medical education research. The student's qualifying and research committees contain faculty from both the Schools of Medicine and Education. All students must have a dissertation proposal approved and they must pass a rigorous written and oral qualifying examination before admission to doctoral candidacy. 
The dissertation proposal must clearly state the research questions or goals, provide a concise but thorough review of the background literature, outline the materials and methods needed for the educational research study, and provide a timeline for implementation and completion of the project. Some of our students have expanded the proposal so as to include the completed literature review and methodology chapters of their dissertation. The PhD advisor and student review multiple versions of the proposal, until the advisor deems the proposal may be submitted to the rest of the committee. This proposal is submitted to the advisory committee at least one month prior to the qualifying examination for review.

The qualifying examination consists of three broad questions, each requiring approximately 6-10 pages of written response. The first question typically sets the stage for a hypothetical educational setting and asks the student to write a brief grant proposal to assess educational outcomes. The second question focuses on a topic or theme related to the student's dissertation proposal, while the third question requires the student to read and critically evaluate/review a published educational research project. The questions are given to the student on a Friday morning and the student has until the following Monday afternoon to complete the written examination.

Within two weeks of completing the written examination, the student meets with the advisory committee for the oral examination. The oral examination is an opportunity for the student to expand upon the written responses and answer questions about the dissertation proposal. Once the student passes the written and oral examinations and has the dissertation proposal approved, she/he may collect data and begin writing the dissertation. Students typically take from 1-3 years after their qualifying exam to complete and defend their dissertation. 


\section{$\underline{\text { Program Outcomes }}$}

Of the 16 students who entered the program since its inception in 2008, one has departed without graduating, 7 have passed their qualifying examinations, and 5 have been awarded their PhDs. Four of the graduates quickly found employment, with 2 of them securing assistant professorships in anatomy departments, one securing an assistant professorship in a surgery department, and one obtaining a lecturer position in a physical education program. One graduate has decided to explore employment opportunities outside of academia. As shown in Table 3, the dissertation projects pursued by the 7 students who passed their qualifying examinations (including the 5 graduates) represent a diverse range of medical education topics, not all of which are related to anatomy education. Students in the program are actively encouraged to broaden their research perspectives to include areas of medical education outside anatomy. It should be noted that the kinds of educational research projects the students pursue tend to differ somewhat between the two campuses (Table 3). The students at IUPUI, the site of the IU Medical Center, have more opportunities to develop research projects with clinical faculty, whereas the students at IUB, the flagship campus of the IU system, have greater access to large undergraduate populations of pre-professional students for their research. This is not to imply that campus location constrains the students' research options, but rather each campus offers unique local advantages that can be exploited for educational research purposes.

As of June 2014, the Education Track students had authored or co-authored 10 journal articles (Barger, 2010; Burr and Guillot, 2012; Collier et al., 2012; Cooper et al., 2012; Fillmore et al., in press; Foo et al., 2013; Keller and Schutte, 2011; Schutte and Braun, 2009; Wilson et al., 2014a; Wilson et al., 2014b). These students also have made over 30 presentations at meetings of the American Association of Anatomists, American Association of Clinical 
Anatomists, Human Anatomy and Physiology Society, and other professional organizations.

Four of the students have won national awards for their educational research (two AAA/LWW Educational Research Scholarship winners, one Educational Research Poster Presentation Winner, and one AAA Educational Research Platform Presentation winner)

\section{LESSONS LEARNED}

Now that the program has survived its initial birthing pains and successfully produced its first graduates, we can share some of the key lessons we learned for the benefit of others who may be contemplating similar programs.

First of all, you need to have strong buy-in from the faculty and support from the leadership at all levels of administration — department, school, and university. The idea for the Education Track in Anatomy PhD Program originated in 2006, when the chair of the Department of Anatomy and Cell Biology established a faculty committee to further develop his concept, create a degree plan, and seek Indiana University's approval to offer an education-focused PhD. It is important to note that we were not seeking to establish a new degree, which is an arduous process requiring approval of the Indiana Commission for Higher Education, but rather to establish an alternate curricular pathway (track) to earn a $\mathrm{PhD}$ in Anatomy and Cell Biology, which was already an approved degree. Nevertheless, our new education track still had to be approved by a succession of university committees before we could officially offer the program to students. We had to overcome some initial skepticism and two fundamental misconceptions about the new track: some committee members perceived the new track as being a "teaching" degree rather than a research degree, and others questioned how a science $\mathrm{PhD}$ could be awarded for doing "non-science" research. Addressing these concerns required a willingness on our part 
to revise the proposal documents to dispel the myth of the "teaching” degree and educate committee members about the nature of research outside of controlled laboratory settings. After a few resubmissions, we were ultimately successful and Indiana University formally approved the new track in 2008. Throughout the approval process, we relied on the advice and guidance of key officials in the Graduate School, which underscores the importance of cultivating the support of knowledgeable institutional officials early in the development of any new training program.

Perhaps the most important element of success has been our close collaboration with the IU School of Education. We knew from the outset that without the enthusiastic participation of the education faculty, the program would not be possible. Education faculty members were consulted in every phase of the program's development, including the selection of education coursework for the doctoral minor, the design of the teaching practicum, and the procedure for the qualifying examination. Since the program’s inception, education faculty members have been involved in all aspects its operation, from admissions decisions to dissertation defenses. They serve as research advisors for the students and provide other tangible services, such as assistance in registering for education courses. Those education faculty members who are most heavily involved in the Education Track in Anatomy PhD Program are offered adjunct appointments in the Department of Anatomy and Cell Biology. For anyone hoping to develop a similar training program, we recommend early discussions with faculty members from your school of education.

\section{FUTURE CHALLENGES}

Although we are encouraged by the program's early successes, there are a few challenges ahead. To some degree, the Education Track in Anatomy PhD Program is at odds with two prevailing trends affecting medical education nationwide; namely, the decline in discipline-specific basic 
science instruction and the corresponding shift to "integrated" curricula (Drake et al., 2009;

Bolender et al., 2013) and the ongoing deterioration of federal research funding to basic science departments, which hurts the financial underpinning of graduate programs. We are presently devising strategies to meet these and other challenges to ensure the long-term viability of our program.

Like many medical schools, Indiana University is revising its medical curriculum. All of the details have yet to be worked out, but current plans call for the elimination of individual, discipline-specific anatomy courses in favor of integrated, multidisciplinary courses and organ system based courses. At present, the Education Track students take their anatomy courses with the medical students. However, the streamlined anatomy education proposed for the new medical curriculum may not be sufficiently in-depth to be suitable for the PhD students, who are expected to become expert anatomy teachers. Nevertheless, integrated curricula are the wave of the future in medical schools, and anatomical educators must be prepared to teach in this new environment. Accordingly, it is important that our Education Track students experience the same integrated curriculum as our medical students, but perhaps with additional educational requirements and expectations to instill a higher order of anatomical expertise. As currently envisioned, the firstyear medical school curriculum will consist of a series of integrated thematic courses, each containing multidisciplinary content previously taught in separate discipline-specific courses. For example, the Human Structure course is planned to contain elements of gross anatomy, histology, embryology, and radiology. The Education Track students will be required to complete this course and its corresponding assessments along with the medical students, and in addition, they will complete advanced assignments and assessments under the direction of anatomy faculty preceptors (e.g., prosections, directed self-study on selected topics, special 
projects, etc.). Other integrated courses containing relevant anatomical and biomedical content will be required as well. In this way, the Education Track students will benefit from the strong clinical orientation of the new curriculum, as well as gain the advanced anatomical knowledge befitting future anatomy educators.

Another challenge is funding. Each student in the program costs the anatomy department about $\$ 30 \mathrm{~K}$ per year to pay his/her teaching stipend, health insurance, and tuition and fees. The program was started at a time when the department could cover these expenses from the indirect costs generated by research grants and from other discretionary funding sources. But this is no longer tenable in the current fiscal environment. Although a few Education Track students can be supported from the tuition revenue of large undergraduate service courses at IUB, the program's continued growth and long-term sustainability will require more robust financing. We have not yet been successful in obtaining a large training grant for the program, but we will continue to pursue whatever external funding opportunities are available. In the meantime, we are developing alternate sources of funding, including the establishment of a dissection-based undergraduate anatomy course on the IUPUI campus. The tuition revenue from this course can provide a supplemental funding stream to help support the program. In addition, the department recently launched the IU Center for Anatomical Sciences Education (IU-CASE), which was created to provide fee-based educational services to colleges and professional schools in Indiana (Brokaw and Jones, 2014). Some of the revenue from IU-CASE can likewise be used to offset program expenses. With these additional funding strategies, we believe the future of the Education Track program is secure.

A third challenge relates to the availability of suitable research mentors for the Education Track students. For the most part, the anatomy department lacks faculty members who are 
sufficiently well versed in educational research to serve on dissertation committees. However, finding qualified faculty members willing to sit on committees and advise our students has not been a problem to date, because we are able to draw upon numerous faculty members from education and other disciplines where pedagogical scholarship is well established. Nevertheless, for our discipline-based doctoral program to grow and thrive, we would like to see more bona fide anatomists in the department become involved in medical education research and participate in the training of our Education Track students. As in any profession, novices in medical education research need faculty role models with whom they can identify and emulate. Fortunately, the medical school provides an avenue for interested faculty to learn about SOTL and medical education research through membership in the Indiana University School of Medicine Academy of Teaching Scholars (2014b), which offers SOTL workshops and other educational experiences in a convenient format for busy faculty members. By encouraging our anatomy colleagues to actively participate in the Academy, we can expand the number of research mentors for our students over time.

\section{IF YOU TRAIN THEM, WILL THEY BE HIRED?}

While there is a recognized need for qualified anatomy educators (McCuskey et al., 2005;

Rizzolo and Drake, 2008; Hedger, 2009), we initially were unsure how the first graduates of our program would be received in the anatomy job market. Would most programs still want to hire individuals with bench-research instead of educational research training? Would our graduates be competitive for tenure-track positions?

We are happy to report that our recent graduates have been actively recruited and hired by several prestigious medical schools throughout the United States. Two of our graduates have 
been hired into tenure track positions, while two others have been hired into multi-year renewable positions. The authors have been approached by several of our colleagues at national meetings, asking us when our other students will be entering the job market. Thus, the job outlook for our education track graduates appears bright for the foreseeable future.

\section{CONCLUSIONS}

The Education Track in Anatomy PhD Program at Indiana University School of Medicine has been successfully implemented and has produced its first graduates, who are fully prepared to assume major teaching responsibilities in all of the anatomical disciplines and to conduct medical education research. We attribute this success to two key elements: (1) strong institutional support, particularly from the leadership of the Graduate School and (2) close collaborative ties with the School of Education. Despite the challenges posed by curricular change and funding limitations, we are confident that our program will continue to thrive and contribute to the next generation of doctoral-level anatomy educators. Judging from the number of inquiries we receive from potential employers about our graduates, we predict that similar programs will arise to supply the growing demand for anatomy educators and medical education researchers. 


\section{ACKNOWLEDGMENTS}

The authors thank the other members of the Education Track in Anatomy PhD Program Development Committee: Nancy Chism (Education), Robert Osgood (Education), Megan Palmer (Education), Dale Saxon (Anatomy), Mark Seifert (Anatomy), Ronald Shew (Anatomy), Laura Torbeck (Surgery), and James Walker (Anatomy). This program would not have been in existence without the support from David Burr (former Chair of Anatomy and Cell Biology at IUSM), Sherry Queener (Associate Dean and Director of the Graduate Office at IUPUI), and Khaula Murtadha (former Executive Associate Dean for the School of Education at IUPUI). In addition, the authors are grateful for the support and encouragement of past and present officials of the Graduate School, including Randy Brutkiewicz, David Daleke, Patricia Gallagher, Simon Rhoades, and James Wimbush. Finally, we thank the anonymous reviewers and editors for their suggestions and edits to this manuscript. 


\section{NOTES ON CONTRIBUTORS}

JAMES J. BROKAW, Ph.D., M.P.H., is an associate professor and vice chair in the Department of Anatomy and Cell Biology at the Indiana University School of Medicine, Indianapolis, Indiana, where he directs the Education Track in Anatomy Ph.D. Program and teaches histology to graduate students and medical students.

VALERIE DEAN O'LOUGHLIN, Ph.D., is an associate professor of anatomy and cell biology in the Medical Sciences Program at the Indiana University School of Medicine, Bloomington, Indiana, where she teaches undergraduate human anatomy, medical gross anatomy, and pedagogical methods in health sciences. Her research interests are in anatomy education and teaching assistant pedagogical development. She is the recipient of numerous teaching awards, including the American Association of Anatomists' Basmajian Award for teaching excellence and outstanding accomplishments in scholarship of education. 


\section{LITERATURE CITED}

Albert M, Hodges B, Regehr G. 2007. Research in medical education: Balancing service and science. Adv Health Sci Educ Theory Pract 12:103-115.

Albertine K. 2008. Creating a teacher-scholar training program for anatomy at the University of Utah School of Medicine. FASEB J 22:241.4.

American Association of Anatomists. 2014. Graduate Programs in Anatomy. Bethesda, MD. URL: http://www.anatomy.org/content/graduate-degree-program-anatomy [accessed 20 May 2014].

Bader D, Dalley AF, Norden JJ, Nanney LB, Pettepher CC, Richmond AW, Wente S, Chalkley R. 2010. Development of a scientist-educator program. FASEB J 24:827.7.

Barger JB. 2010. Teaching from the trenches: How my experiences as a teacher and as an anatomy education PhD student have changed the way I teach. HAPS Educator 10:22-24.

Barger JB. (in progress) Improving undergraduate anatomy laboratory grades and study skills through teaching visual literacy and observation skills. Indiana University: Bloomington, IN. Doctorate of Philosophy Dissertation. 
Bernard HR. 2006. Research Methods in Anthropology: Qualitative and Quantitative Approaches. 4th Ed. Lanham, MD: AltaMira Press. 824 p.

Boet S, Sharma S, Goldman J, Reeves S. 2012. Review article: Medical education research: An overview of methods. Can J Anesth 59:159-170.

Bolender DL, Ettarh R, Jerrett DP, Laherty RF. 2013. Curriculum integration = course disintegration: What does this mean for anatomy? Anat Sci Educ 6:205-208.

Boyer EL. 1990. Scholarship reconsidered: Priorities of the professoriate. San Francisco, CA: Jossey-Bass Publishers. 147 p.

Brokaw JJ, Jones KJ. 2014. Outsourcing anatomists: A model for expanding educational outreach and providing supplemental revenue to anatomy departments. FASEB J 28:721.22.

Bunniss S, Kelly DR. 2010. Research paradigms in medical education research. Med Educ 44:358-366.

Burr DB, Guillot GM. 2012. Almost invisible, often ignored: Periosteum, the living lace of bone. Medicographia 34:221-227.

Bush SD, Pelaez NJ, Rudd JA, Stevens MT, Tanner KD, Williams KS. 2008. Science faculty with education specialties. Science 322:1795-1796. 
Carney PA, Nierenberg DW, Pipas CF, Brooks WB, Stukel TA, Keller AM. 2004. Educational epidemiology: Applying population-based design and analytic approaches to study medical education. JAMA 292:1044-1050.

Cassidy KM. (in progress) Embryology in the medical curriculum: Past and current practices. Indiana University: Bloomington, IN. Doctorate of Philosophy Dissertation.

Collier L, Dunham S, Braun MW, O’Loughlin VD. 2012. Optical versus virtual: Teaching assistant perceptions of the use of virtual microscopy in an undergraduate human anatomy course. Anat Sci Educ 5:10-19.

Cooper DD, Wilson AB, Huffman GN, Humbert AJ. 2012. Medical students' perception of residents as teachers: Comparing effectiveness of residents and faculty during simulation debriefings. J Grad Med Educ 4:486-489.

Creighton University School of Medicine. 2014. Masters Program in Clinical Anatomy. Omaha, NE. URL:

http://medschool.creighton.edu/medicine/departments/biomedicalsciences/graduateprograms/msi nclinicalanatomy/index.php [accessed 20 May 2014].

Curry LA, Nembhard IM, Bradley EH. 2009. Qualitative and mixed methods provide unique contributions to outcomes research. Circulation 119:1442-1452. 
Drake RL, McBride JM, Lachman N, Pawlina W. 2009. Medical education in the anatomical sciences: The winds of change continue to blow. Anat Sci Educ 2:253-259.

Fillmore E, Helfenbein R, Seifert M. (in press) Dissecting anatomy: Exploring the perspective of the repeating first year medical student in both an open and peer teaching gross anatomy laboratory format. Med Sci Educ.

Foo JL, Martinez-Escobar M, Juhnke B, Cassidy K, Hisley K, Lobe T, Winer, E. 2013. Evaluating mental workload of two-dimensional and three-dimensional visualization for anatomical structure localization. J Laparoendosc Adv Surg Tech 23:65-70.

Fraher JP, Evans DJ. 2009. Training tomorrow's anatomists today: A partnership approach. Anat Sci Educ 2:119-125.

Glassick CE, Huber MT, Maeroff GI. 1997. Scholarship assessed: Evaluation of the professoriate. San Francisco, CA: Jossey-Bass Publishers. 130 p.

Griffith LM, O’Loughlin VD, Kearns KD, Braun M, Heacock I. 2013. Chapter 4: A Pedagogy Course’s Influence on Graduate Students’ Self-Awareness as Teacher-Scholars. In: L. Border (ed.) Studies in Graduate and Professional Student Development, No. 13, pp. 59-82, Stillwater, OK: New Forums Press. 
Guillot GM. 2014. Does time matter? A search for meaningful medical school faculty cohorts. Indiana University: Indianapolis, IN. Doctorate of Philosophy Dissertation. 267 p.

Hedger B. 2009. Anatomy of an evolution. AAMC Reporter 18:8-9.

Henkin K. 2013. Understanding interprofessional education: A multiple-case study of students, faculty, and administrators. Indiana University: Indianapolis, IN. Doctorate of Philosophy Dissertation. 149 p.

Hildebrandt S. 2010. Lessons to be learned from the history of anatomical teaching in the United States: The example of the University of Michigan. Anat Sci Educ 3:202-212.

Hoffman LA. 2014. An exploration of reflective writing and self-assessments to explain professionalism lapses among medical students. Indiana University: Indianapolis, IN. Doctorate of Philosophy Dissertation. 140 p.

Indiana University School of Medicine. 2014a. Graduate Division. Indianapolis, IN. URL: http://grad.medicine.iu.edu/degree-programs/ibmg/ [accessed 8 June 2014].

Indiana University School of Medicine. 2014b. Academy of Teaching Scholars. Indianapolis, IN. URL: http://faculty.medicine.iu.edu/faculty-development/teaching-development/academy-ofteaching-scholars/ [accessed 7 June 2014]. 
Keller J, Schutte A. 2011. What we learned from teaching about learning. HAPS Educator 15:2325.

Kennedy TJ, Lingard LA. 2006. Making sense of grounded theory in medical education. Med Educ 40:101-108.

Louisiana State University School of Medicine. 2014. Graduate Program in Clinical Anatomy. New Orleans, LA. URL:

http://www.medschool.lsuhsc.edu/cell_biology/program_ca_overview.aspx [accessed 20 May 2014].

McCuskey RS, Carmichael SW, Kirch DG. 2005. The importance of anatomy in health professions education and the shortage of qualified educators. Acad Med 80:349-351.

Merriam SB. 1992. Qualitative Research and Case Study Applications in Education. San Francisco, CA: Jossey-Bass Publishers. 275 p.

Merriam SB, Simpson EL. 2000. A guide to research for educators and trainers of adults. $2^{\text {nd }}$ ed. Malabar, FL: Krieger Publishing Company. 239 p.

O’Loughlin VD. Biological Anthropologists: Tomorrow’s Anatomy Educators? FASEB J 19:A790. 
Riehl C. 2006. Feeling better: A comparison of medical research and education research. Educ Res 35:24-29.

Purdue University College of Veterinary Medicine. 2014. Basic Medical Sciences Graduate Program, West Lafayette, IN. URL: http://www.vet.purdue.edu/bms/index.php [accessed 27 May 2014].

Rizzolo LJ, Drake RL. 2008. Anatomists debate the value of a teaching credential. Anat Sci Educ 1:60-67.

Schifferdecker KE, Reed VA. 2009. Using mixed methods research in medical education: Basic guidelines for researchers. Med Educ 43:637-644.

Schutte AF. 2013. Remediation trends in an undergraduate anatomy course and assessment of an anatomy supplemental study skills course. Indiana University: Bloomington, IN. Doctorate of Philosophy Dissertation. 200 p.

Schutte A, Braun M. 2009. Virtual microscopy: Experiences of a large undergraduate anatomy course. HAPS Educator 1:39-42.

Tulane University School of Medicine. 2014. Masters Program in Clinical Anatomy. New Orleans, LA. URL: http://tulane.edu/som/departments/scb/masters/ [accessed 20 May 2014]. 
University of Mississippi Medical Center. 2014. Graduate Program in Clinical Anatomy.

Jackson, MS. URL: http://www.umc.edu/ClinAnatProgram/ [accessed 20 May 2014].

University of Nebraska Medical Center. 2014. Anatomy Teaching Track PhD Program. Omaha, NE. URL: http://www.unmc.edu/genetics/doctor_philosophy_program.htm [accessed 26 May 2014].

Virginia Commonwealth University Medical Center. 2014. Anatomy and Neurobiology PhD Program. Richmond, VA. URL: http://www.anatomy.vcu.edu/programs/phd/index.html [accessed 20 May 2014].

Western University. 2014. Masters Program in Clinical Anatomy. London, Ontario. URL: http://www.uwo.ca/anatomy/graduate/msclinic.html [accessed 20 May 2014].

Wilson AB. 2013. A psychometric evaluation of script concordance tests for measuring clinical reasoning. Indiana University: Indianapolis, IN. Doctorate of Philosophy Dissertation. 141 p.

Wilson AB, Pike GR, Humbert AJ. 2014a. Analyzing script concordance test scoring methods and items by difficulty and type. Teach Learn Med 26:135-145.

Wilson AB, Pike GR, Humbert AJ. 2014b. Preliminary factor analyses raise concerns about script concordance test utility. Med Sci Educ 24:51-58. 
Table 1: Curriculum of the Education Track PhD Program in Anatomy and Cell Biology at Indiana University

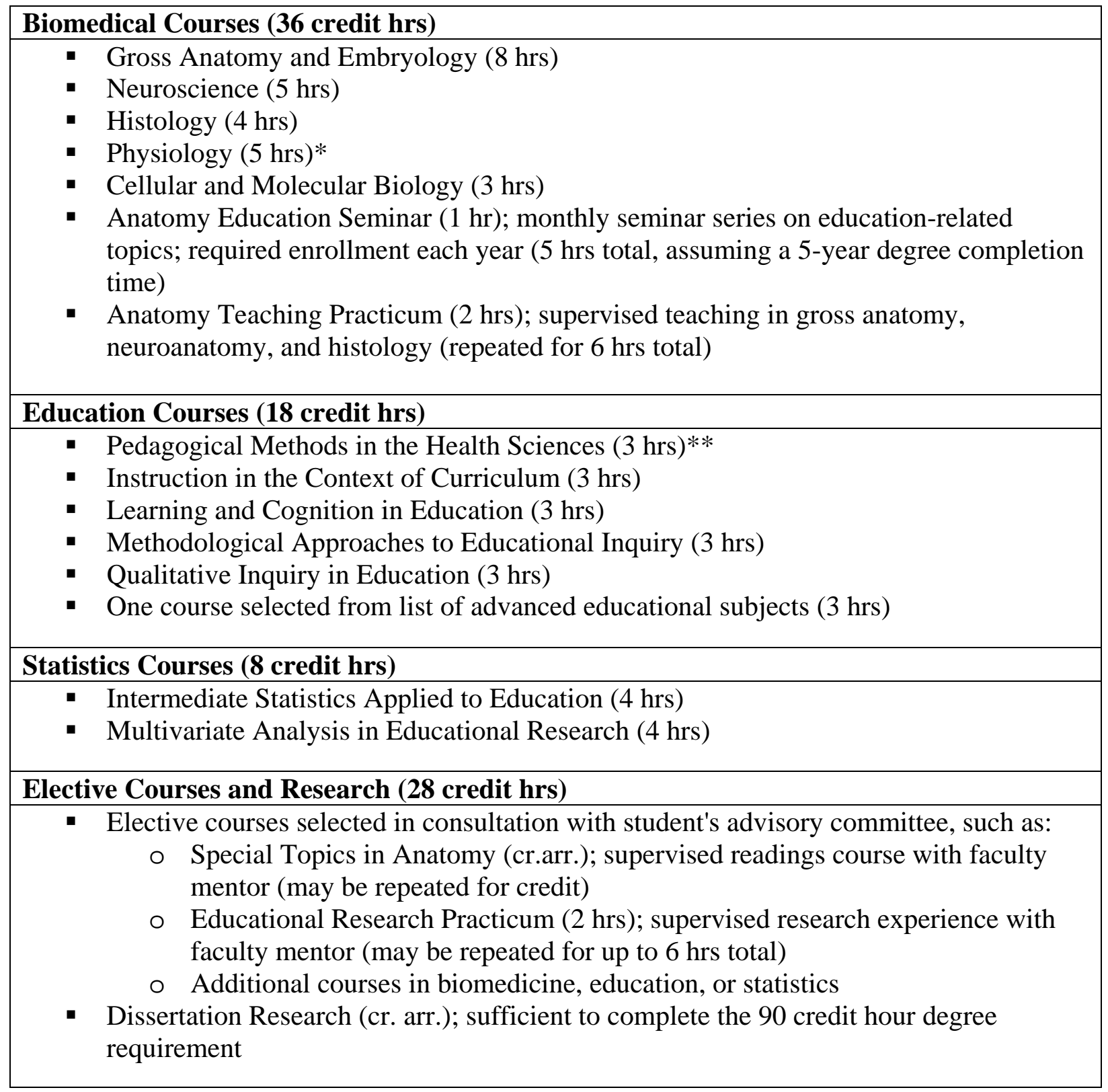

*On the Bloomington campus, the medical physiology course is 8 credit hours, which increases the total for biomedical courses to $39 \mathrm{hrs}$, and decreases the total for elective courses and research to 25 hrs.

**Offered through the Medical Sciences Program at Bloomington and taught by anatomy faculty, not education faculty. 
Table 2: Academic Degrees of 16 Students Who Entered the Education Track PhD

Program in Anatomy and Cell Biology at Indiana University, 2008-2014

\begin{tabular}{|l|l|}
\hline Bachelor's Degrees* \\
\hline - Anthropology (1) \\
- Biochemistry (1) \\
- Biology (8) \\
- History (1) \\
- Philosophy (1) \\
- Physician Assistant (1) \\
- Physics and Math (1) \\
- Political Science (1) \\
- Spanish (1) \\
\hline - Biology (1) \\
- Education (1) \\
- Entomology (1) \\
- Kuman Anatomy (7) \\
- Medical Illustration (1) \\
\hline
\end{tabular}

*Four of the 16 entering students possessed two bachelor's degrees, giving 20 degrees total.

**All but two of the 16 entering students possessed a master's degree. 
Table 3: Dissertation Projects of 7 Doctoral Candidates in the Education Track PhD Program in Anatomy and Cell Biology at Indiana University, 2008-2014

\begin{tabular}{|l|c|c|}
\hline \multicolumn{1}{|c|}{ Project Title } & Study Type & Campus \\
\hline $\begin{array}{l}\text { Remediation Trends in an Undergraduate Anatomy } \\
\text { Course and Assessment of an Anatomy Supplemental } \\
\text { Study Skills Course (Schutte, 2013) }\end{array}$ & Mixed Methods & Bloomington \\
\hline $\begin{array}{l}\text { Understanding Inter-Professional Education: A Multiple } \\
\text { Case Study of Students, Faculty, and Administrators } \\
\text { (Henkin, 2013) }\end{array}$ & Qualitative & Indianapolis \\
\hline $\begin{array}{l}\text { A Psychometric Evaluation of Script Concordance } \\
\text { Tests for Measuring Clinical Reasoning (Wilson, 2013) }\end{array}$ & Quantitative & Indianapolis \\
\hline $\begin{array}{l}\text { An Exploration of Reflective Writing and Self- } \\
\text { Assessments to Explain Professionalism Lapses Among } \\
\text { Medical Students (Hoffman, 2014) }\end{array}$ & Mixed Methods & Indianapolis \\
\hline $\begin{array}{l}\text { Does Time Matter? A Search for Meaningful Medical } \\
\text { School Faculty Cohorts (Guillot, 2014) }\end{array}$ & Quantitative & Indianapolis \\
\hline $\begin{array}{l}\text { Improving Undergraduate Anatomy Laboratory Grades } \\
\text { and Study Skills Through Teaching Visual Literacy and } \\
\text { Observation Skills (Barger, in progress) }\end{array}$ & Mixed Methods & Bloomington \\
\hline $\begin{array}{l}\text { Embryology in the Medical Curriculum: Past and } \\
\text { Current Practices (Cassidy, in progress) }\end{array}$ & Mixed Methods & Bloomington \\
\hline
\end{tabular}

